Article

\title{
Melt-Mixed Thermoplastic Nanocomposite Containing Carbon Nanotubes and Titanium Dioxide for Flame Retardancy Applications
}

\author{
C. Cabello-Alvarado ${ }^{1,2}{ }^{\text {, P. Reyes-Rodríguez }}{ }^{2}$, M. Andrade-Guel ${ }^{2}$, G. Cadenas-Pliego ${ }^{2, *(1)}$, \\ M. Pérez-Alvarez ${ }^{3}$, V.J. Cruz-Delgado ${ }^{4}$, L. Melo-López ${ }^{1,2}$, Z.V. Quiñones-Jurado ${ }^{5}$ and \\ C.A. Ávila-Orta $2, *$ (D) \\ 1 CONACYT-Consorcio de Investigación y de Innovación del Estado de Tlaxcala, C.P. 90000 Tlaxcala, Mexico \\ 2 Centro de Investigación en Química Aplicada, Saltillo, 25315 Coahuila, Mexico \\ 3 CONACYT-Instituto Mexicano del Petróleo, Eje Central Lázaro Cárdenas Norte 152, \\ 07730 Ciudad de Mexico, Mexico \\ 4 CONACYT-Unidad de Materiales, Centro de Investigación Científica de Yucatán, A.C., Mérida C.P. 97205, \\ Yucatán, Mexico \\ 5 Innovación y Desarrollo en Materiales Avanzados A.C., Grupo POLYnnova, Carr. San Luis \\ Potosí-Guadalajara 1510, Nivel 3, Local 12, Lomas del Tecnológico, San Luis Potosí S.L.P. C.P. 78211 Mexico, \\ Mexico \\ * Correspondence: gregorio.cadenas@ciqa.edu.mx (G.C.-P.); carlos.avila@ciqa.edu.mx (C.A.A.-O.)
}

Received: 20 June 2019; Accepted: 15 July 2019; Published: 19 July 2019

\begin{abstract}
The study of polymeric nanocomposites is a possible alternative to conventional flame retardants. The aim of the present work is to investigate the effects of carbon-nanotubes (CNT) and $\mathrm{TiO}_{2}$ nanoparticles (NPs) on the thermo-mechanical, flammability, and electrical properties of polypropylene (PP). In this work, $\mathrm{PP}-\mathrm{TiO}_{2} / \mathrm{CNT}$ nanocomposites were obtained with $\mathrm{TiO}_{2} / \mathrm{CNT}$ mixtures (ratio 1:2) through the melt extrusion process, with different weight percentage of nanoparticles $\left(1,5\right.$, and 10 wt \%). The $\mathrm{PP}-\mathrm{TiO}_{2} / \mathrm{CNT}$ nanocomposites were characterized by DSC, TGA, MFI, FTIR, XRD, and SEM. It was possible to determine that the thermal stability of the PP increases when increasing the content of NPs. A contrary situation is observed in the degree of crystallinity and thermo-oxidative degradation, which decreased with respect to pure PP. The $\mathrm{TiO}_{2} \mathrm{NPs}$ undergo coalition and increase their size at a lower viscosity of the nanocomposite ( 1 and $5 \mathrm{wt} \%$ ). The mechanical properties decreased slightly, however, the Young's modulus presented an improvement of $10 \%$ as well as electrical conductivity, this behavior was noted in nanocomposites of $10 \mathrm{wt} \%$ of NPs. Flammability properties were measured with a cone calorimeter, and a reduction in the peak heat release rate was observed in nanocomposites with contents of nanoparticles of 5 and $10 \mathrm{wt} \%$
\end{abstract}

Keywords: nanocomposite; polypropylene; carbon nanotube; titanium dioxide

\section{Introduction}

Avoiding or preventing fires helps decrease injuries or human losses in automotive industry [1]. Different causes arise for these types of events, such as mechanical problems, electrical failures, or car accidents, since most automotive liquids are flammable. The automotive parts manufactured with different polymers are flammable and must be protected against fires [2]. For these materials, some flame retardants are applied only in the exterior, and some carbonaceous and ceramic films help to improve their flame-retardant effect [3-6]. 
One of the most common polymers used to obtain polymeric nanocomposites is polypropylene (PP), which is a semi-crystalline thermoplastic widely used in applications such as textile, films, bottles production, and piping, and is also the most used in the automotive industry [7-9]. However, PP has some limitations, such as being sensitive to heat and oxidative degradation, as well as its fragility. This polymer by itself is prone to crack or vulnerable to mechanical failures and, like most polymers, has low electrical and thermal conductivity; for these reasons, the addition of nanoparticles or nanocharges has been adopted with the purpose of changing properties of neat polymer [10,11].

The incorporation of nanoparticles to improve polymers properties depends in great extent on wt $\%$ of nanocharge used. A clear example of this effect was observed in ethylene vinyl acetate (EVA) nanocomposites with different nanoclay content (1-15 wt \%). Thermal stabilization was achieved when the nanoclay content was between 2.5-10 wt \%. Outside this range, the EVA thermal stability was not significant. In general, polymers properties are improved with low percentages in weight of nanocharge $(<3 \mathrm{wt} \%)$, however, several researchers have studied high nanocharges percentages [12-14]. The flame-retardant effect of carbon nanotubes (CNT) has been researched in epoxy, polystyrene, polyaniline, polypropylene, and polyurethane polymeric matrixes, and the polymer/CNT nanocomposites are effective in producing continuous structured network $[15,16]$. A significant reduction in the peak heat release rate was observed in PP/CNT nanocomposites that contain $0.5-4.0 \mathrm{wt} \%$ of CNT [17].

Antunes et al. obtained PP and carbon nanofibers (CNF) nanocomposites by melting extrusion with electrical properties, and, taking into account the percolation threshold, formation of this nanocomposite showed similar conduction of Hall effect at CNF concentrations of $5 \%$. At higher $\mathrm{CNF}$ contents, no significant improvements were achieved since tunnels conduction decreased in the extent polymer crystallinity increased [18]. The PP/CNT nanocomposites improve their electrical properties when increasing CNT content; the electrical percolation threshold was reached at CNT content of 1 and $2 \mathrm{wt} \%$ [19].

The addition of inorganic nanoparticles in polymeric matrix and the combination of different types of particles are used for obtaining multifunctional materials. The nanoparticles such as $\mathrm{TiO}_{2}$, $\mathrm{SiO}_{2}, \mathrm{CaCO}_{3}, \mathrm{ZnO}, \mathrm{Ag}$, and nanoclays help to improve the physical and mechanical properties as well as flame retardant activity, thermal stability, oxidation, and permeability, among others [20,21]. The titanium dioxide $\left(\mathrm{TiO}_{2}\right)$ nanoparticles are ceramic materials widely used thanks to their properties as reinforcement for polymeric materials due to their long-term stability. Aydemir et al. [22] report the production of $\mathrm{PP} / \mathrm{TiO}_{2}$ nanocomposites, where mechanical properties as stress resistance and elasticity module were widely favored with the addition of $\mathrm{TiO}_{2}$ in the polymeric matrix. Esthappan et al. [23] report the production of $\mathrm{PP}_{-} \mathrm{TiO}_{2}$ nanocomposites for use like fibers, since addition of $\mathrm{TiO}_{2}$ nanoparticles improve thermal stability of polypropylene, besides improving polymer crystallinity.

There are different methods for polymeric nanocomposites synthesis. Among them is found the melting extrusion method, which favors homogeneous dispersion of nanocharges, and is considered eco-friendly and economically viable for the industry, since it does not require the use of solvents and can yield high production volumes [24,25].

This research work studies the synthesis and evaluation of nanocomposites of polypropylene with $\mathrm{TiO}_{2}$ and $\mathrm{CNT}$ nanoparticles blend. The nanocomposites were obtained by melt extrusion method. The purpose of using these additives was to improve the properties of thermal stability, electrical conductivity, and flame retardant of PP.

\section{Materials and Methods}

\subsection{Material}

MWNTC were provided by Cheap Tubes Inc. and have an average diameter from 20 to $40 \mathrm{~nm}$, length of $10-30 \mu \mathrm{m}$, and purity of $\geq 90 \% \mathrm{wt}$. The $\mathrm{TiO}_{2}$ nanoparticles were provided by DuPont, with a particle size from approximately $200 \mathrm{~nm}$ and semispherical morphology rutile phase. The polymeric 
matrix PP with fluid index of $0.76 \mathrm{~g} / 10 \mathrm{~min}$. supplied by Polímeros Nacionales (México, México) was used.

\subsection{Methods}

Synthesis of PP/CNT Nanocomposites

The preparation of PP nanocomposites with a mixture of $\mathrm{TiO}_{2} / \mathrm{CNT}$ was performed by the melting extrusion process. The masterbatch preparation of $\mathrm{PP} / \mathrm{TiO}_{2} / \mathrm{CNT}$ was conducted in a twin-screw extruder lab size from Thermo Scientific model Prism TSE-24MC, screw diameter of $24 \mathrm{~mm}, \mathrm{~L} / \mathrm{D}$ ratio 40:1, and temperature profile of $180^{\circ} \mathrm{C}$ and rotational speed of $100 \mathrm{rpm}$. Low shear strengths were used to improve particles dispersion in polymeric matrix in the screw configuration, which is shown in Figure 1.

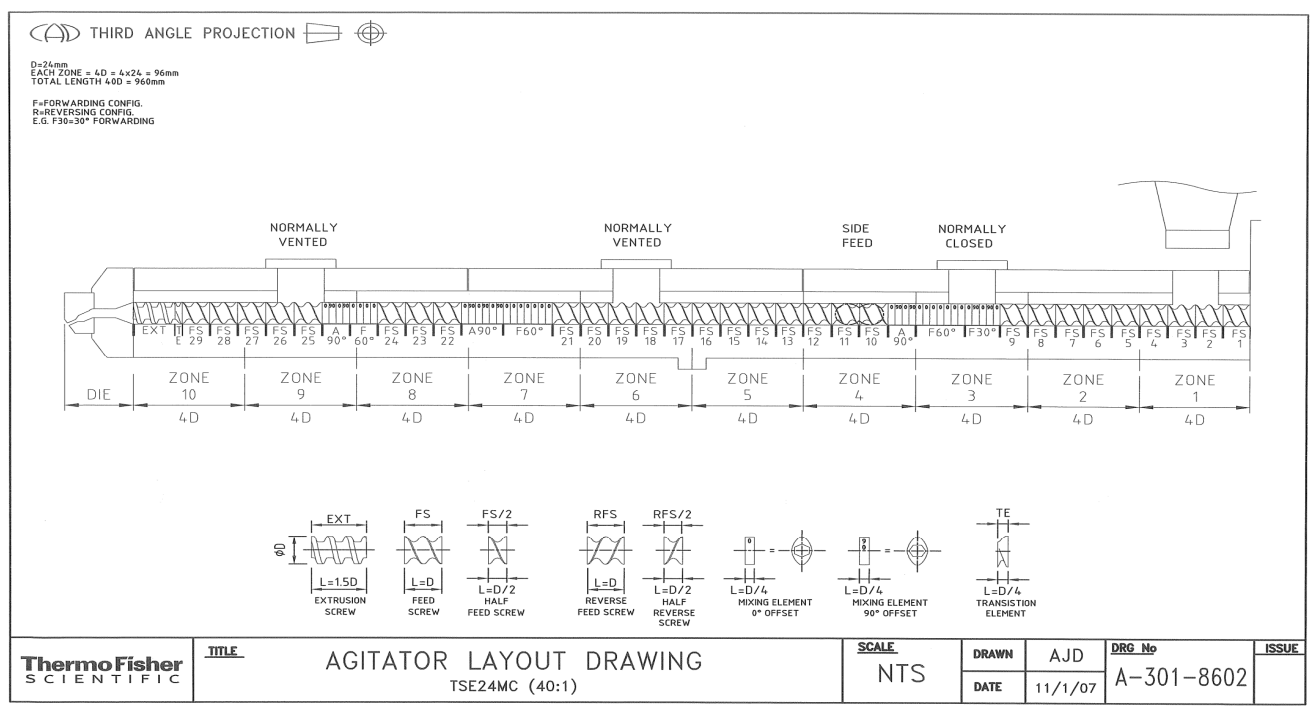

Figure 1. Configuration for the extrusion process.

There were prepared three nanocomposites of PP $(1,5,10 \mathrm{wt} \%)$ with different weight percentages of $\mathrm{CNT}$ and titanium dioxide $\left(\mathrm{TiO}_{2}\right)$ nanoparticles. Table 1 lists the amounts used. The nanocomposites are identified as $\mathrm{PP}-\mathrm{TiO}_{2} / \mathrm{CNT}-\mathrm{X}$, where $\mathrm{X}$ means the weight percentage of nanocharges $\left(\mathrm{CNT}+\mathrm{TiO}_{2}\right)$ and PP without particles. It was decided to use these percentages due to some authors reporting improvements in the physical and chemical properties of polymers when adding CNT [26].

Table 1. Compounding formulations polypropylene-carbon-nanotubes ( $\left.\mathrm{PP}-\mathrm{TiO}_{2} / \mathrm{CNT}-\mathrm{X}\right)$.

\begin{tabular}{cccc}
\hline Sample & $\left.\mathbf{C N T}+\mathbf{T i O}_{\mathbf{2}} \mathbf{( w t} \%\right)$ & $\mathbf{P P}(\mathbf{g})$ & $\mathbf{T i O}_{2} / \mathrm{CNT} \mathbf{( g )}$ \\
\hline $\mathrm{PP}$ & 0 & 200 & 0 \\
$\mathrm{PP}-\mathrm{TiO}_{2} / \mathrm{CNT}-1$ & 1 & 198 & 2 \\
$\mathrm{PP}-T i O_{2} / \mathrm{CNT}-5$ & 5 & 190 & 10 \\
${\mathrm{PP}-\mathrm{TiO}_{2} / \mathrm{CNT}-10}$ & 10 & 180 & 20 \\
\hline
\end{tabular}

\subsection{Characterization}

\subsubsection{X-Ray Diffraction (XRD)}

For nanocomposites structural analysis, wide angle X-ray diffraction technique (WAXD) was used, conducted in diffractometer from Siemens model D-5000, operating at current intensity of $25 \mathrm{~mA}$ and voltage of $35 \mathrm{kV}$, to obtain $\mathrm{Cu} \mathrm{K} \alpha$ radiation with a wavelength equivalent to $1.54056 \AA$. 


\subsubsection{Fourier Transform Infrared Spectroscopy FTIR (ATR)}

For FT-IR analysis a Thermo Nicolet infrared spectrometer, model MAGNA 550 (GMI, Minneapolis, Minnesota, USA), was used. The conditions at which these analyses were performed are the following: scanner 100, resolution of $16 \mathrm{~cm}^{-1}$, and wave interval from 4000 to $500 \mathrm{~cm}^{-1}$ with ATR support.

\subsubsection{Melt Flow Index (MFI)}

The melt flow index was obtained using Dynisco plastometer, which consists of heating a barrel to melt material. Aw piston press was loaded with melted material to make it flow through die with a circular orifice of $2.1 \mathrm{~mm}$ of diameter and length of $8 \mathrm{~mm}$. This test was performed under ASTM D1238-40 standard.

\subsubsection{Thermal Stability (DSC and TGA)}

For evaluating thermal properties, thermogravimetric analysis was used. The equipment used was Dupont Instruments model 951 (TA Instruments, New Castle, Pennsylvania, USA), operated at heating rate of $10{ }^{\circ} \mathrm{C} / \mathrm{min}$ in nitrogen atmosphere with gas flow of $50 \mathrm{~mL} / \mathrm{min}$. The approximate weight of samples was of $10 \mathrm{mg}$ and was analyzed in the interval of temperature from 25 to $800{ }^{\circ} \mathrm{C}$. The Differential Scan Calorimetry was carried out under ASTM D3418 standard and thermal analyzer Q2000 from TA Instruments (New Castle, Pennsylvania, USA), with standard cell.

The degree of crystallinity $\left(X_{c}\right)$ was calculated using with the following equation:

$$
X_{c}(\%)=\left[\frac{\Delta H_{f}}{(1-\varnothing) \Delta H^{*}}\right] \times(100)
$$

where $\Delta H_{f}$ is the fusion heat or formation of PP in the nanocomposites, $\Delta H^{*}$ is the formation heat of PP with crystallinity of $100 \%$ equivalent to $209 \mathrm{~J} / \mathrm{g}$ and $\varnothing$ is the fraction of weight of $\mathrm{TiO}_{2}$ and CNT [27].

\subsubsection{Scanning Electron Microscopy (SEM)}

For the determination of size and morphology for each one of the components, a JOEL Field Emission Scanning Electron Microscope model JSM-7401F (JEOL, Peabody, MA, USA) was used. The microscope acceleration voltage was of $3.0 \mathrm{kV}$ using the LEI secondary electrons detector.

\subsubsection{Mechanical Properties Analysis}

For measuring mechanical properties, tension tests were performed on model 4301 Instron universal machine (Instron corporation, Norwood, Massachusetts, USA), at $5 \mathrm{~mm} \mathrm{~min}^{-1}$, with different lengthening percentages $(0,60,400$, and $700 \%)$.

\subsubsection{Electrical Resistivity}

These evaluations were made three times. For electrical resistivity, thickness plates were used, and they were covered in both sides with silver paint. The device used was Keysight LCR [inductance (L), capacitance (C), and resistance (R)] meter model E $4980 \mathrm{~A}$, over $20 \mathrm{~Hz}$ to $2 \mathrm{MHz}$ and LCR meter model ZM2372, from $0.001 \mathrm{~Hz}$ to $100 \mathrm{kHz}$. The electrical conductivity was calculated using the Equation (2) [28]:

$$
\sigma=\frac{1}{\rho}
$$

where $\sigma$ is the electrical conductivity and $\rho$ is the electrical resistivity. 


\subsubsection{Calorimetric Cone}

For evaluation of combustion properties of nanocomposites, a calorimetric cone from Fire Testing Technology was used following the method described under ASTM E1354 standard. The evaluation of samples was made in horizontal position and the position of heat flow generator cone was also in horizontal position. The samples measurements were from $100 \mathrm{~mm} \times 100 \mathrm{~mm} \times 3 \mathrm{~mm}$ and were obtained by compression molding. The calorimetric cone was calibrated at $5 \mathrm{~kW}$ with methane flow, the flow in the extraction duct was of $24 \mathrm{~L} / \mathrm{s}$, and the analyzer was calibrated with $20.95 \%$ of oxygen. Heat flow for assessing samples was $35 \mathrm{~kW} / \mathrm{m}^{2}$. The sample was placed in aluminum paper tray with same dimension of sample and $1 \mathrm{~cm}$ height, leaving the surface to evaluate with free area of $100 \mathrm{~mm}^{2}$. This was placed in the sample holder adjusting distance between cone and surface of sample to $25 \mathrm{~mm}$.

\section{Results and Discussion}

\subsection{X-ray Diffraction}

In Figure 2, there are shown PP, and $\mathrm{CNT}$ and $\mathrm{TiO}_{2}$ nanoparticles $\mathrm{XRD}$ diffractograms with the aim to compare diffraction patterns of base materials with nanocomposites of $\mathrm{PP}-\mathrm{TiO}_{2} / \mathrm{CNT}$. The diffractograms of samples with PP showed signals located at $2 \theta$ angles of 14.1, 16.1, 16.8, 21.5 and $25.5^{\circ}$, which correspond to planes (110), (300), (040), (111), and (060) of PP crystalline phase, and the other signal located at $2 \theta$ angle of $21.1^{\circ}$ can be correlated to phases $\alpha(111)$ and $\beta(311)$ of PP. In the nanocomposites, signals characteristic of CNT $\left[29.1^{\circ}\right.$ plane (100)] were not detected, since polypropylene signals are superimposed. The nanocomposites containing $\mathrm{TiO}_{2}$ showed the characteristic signal located at $28.5^{\circ}(110)[29,30]$.

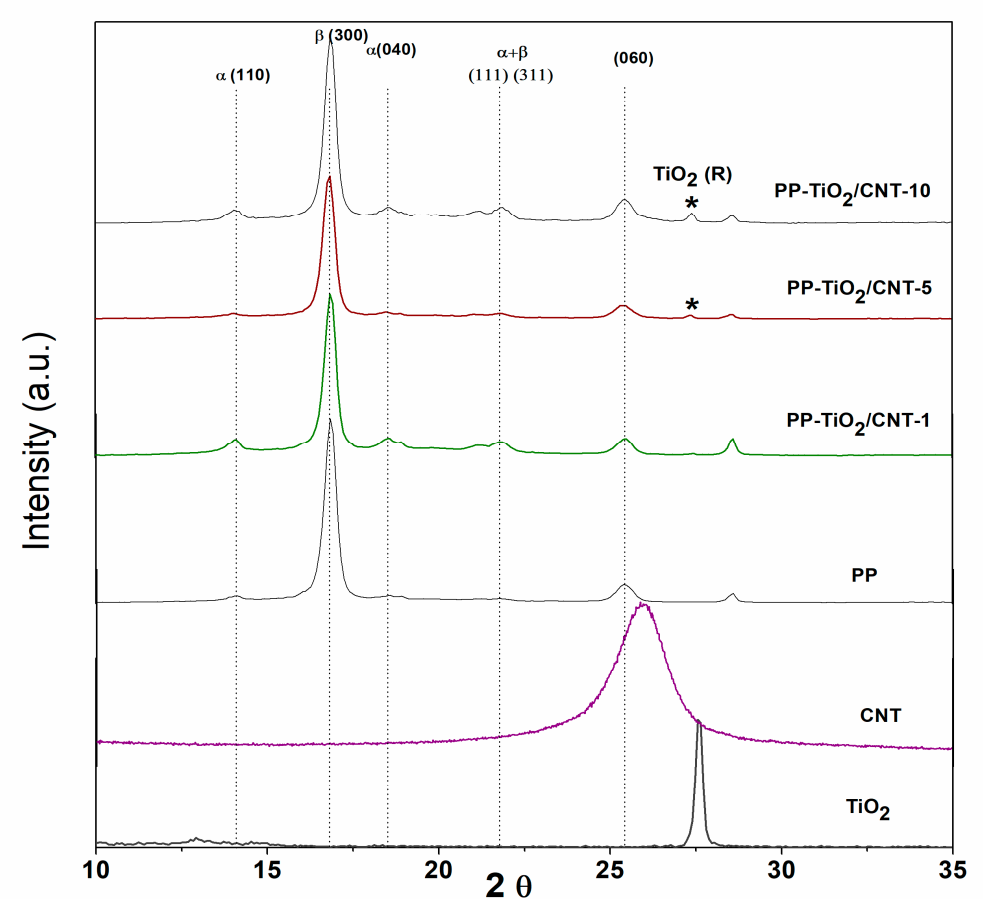

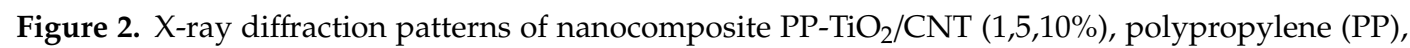
carbon-nanotubes $(\mathrm{CNT})$ and $\mathrm{TiO}_{2}$.

The crystallinity can be more affected in the $\mathrm{PP}-\mathrm{TiO}_{2} / \mathrm{CNT}-10$ nanocomposite where change related to polymer crystallinity is detected, increasing the nanocomposites signals. In 2013, Wang et al. studied PP nanocomposites with carboxylate nucleating agent (NTC) and the XRD diffractograms showed a signal at $2 \theta$ of $16.51^{\circ}$, which corresponds to crystalline plane (300) of $\beta$-hexagonal crystalline phase, showing that NTC has clear effect of nucleation in PP [31]. Similar results were obtained by Zohrevand 
et al., in 2014 when studying $\mathrm{PP} / \mathrm{TiO}_{2}$ nanocomposites with 1,3 , and $5 \mathrm{vol} \%$. The intensity of this $\beta$ phase is significant only in nanocomposites with $1 \mathrm{vol} \%$, while with 3 and $5 \mathrm{vol} \%$, the intensity of peak is not significant. Besides this, they report that presence of a peak in $2 \theta$ at $21.1^{\circ}$ can be correlated to alpha and beta phase, and these results confirm that presence of $\mathrm{TiO}_{2}$ nanoparticles induces $\beta$-form crystal formation in PP [32].

\subsection{Fourier Transform Infrared FTIR (ATR)}

The spectroscopy results of FT-IR are shown in Figure 3, where it can be noted that nanocomposites (Figure 3d-f) show transmittance signals characteristic of PP located in the range from 3000 to $2800 \mathrm{~cm}^{-1}$, which correspond to asymmetric and symmetric $\mathrm{C}-\mathrm{H}$ stretching vibration of methylene $\left(\mathrm{CH}_{2}\right)$ and methyl $\left(\mathrm{CH}_{3}\right)$ groups. Signals corresponding to flexions of $\mathrm{CH}_{2}$ and $\mathrm{CH}_{3}$ bonds are localized in $1448 \mathrm{~cm}^{-1}$ and $1373 \mathrm{~cm}^{-1}$, respectively. The FT-IR spectrum of $\mathrm{TiO}_{2}$ nanoparticles (Figure 3a) shows three signals: in $3438 \mathrm{~cm}^{-1}$ corresponding to hydroxyl group $\mathrm{O}-\mathrm{H}$, in $1624 \mathrm{~cm}^{-1}$ of Ti-OH, and at $735 \mathrm{~cm}^{-1}$ corresponding to Ti-O bond [33,34]. The FT-IR spectrum of CNT is shown in Figure 3b, and the signal of stretching of O-H bonds was detected at $3464 \mathrm{~cm}^{-1}$, which existing in CNT. Also, in 2918 and $2841 \mathrm{~cm}^{-1}$, signals of $\mathrm{C}-\mathrm{H}$ bond were detected, and in $1650 \mathrm{~cm}^{-1}$ there were detected signals from stretching of $\mathrm{C}=\mathrm{C}$ vibrations and at $1041 \mathrm{~cm}^{-1}$ of $\mathrm{C}-\mathrm{O}$ bond $[35,36]$.

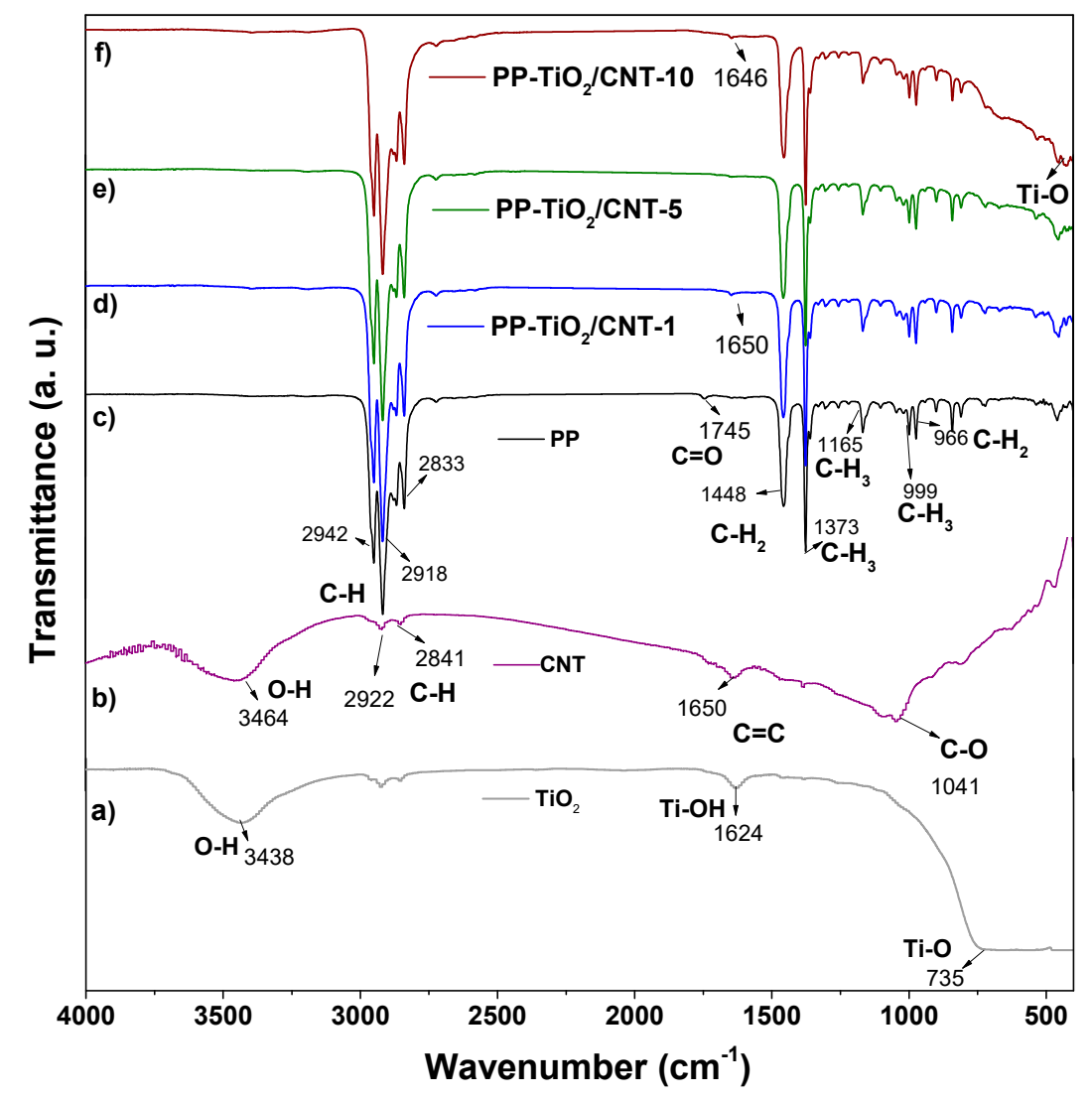

Figure 3. FT-IR spectra of nanocomposite $\mathrm{PP}_{-} \mathrm{TiO}_{2} / \mathrm{CNT}(1,5$ and $10 \%)$, polypropylene (PP), carbon nanotubes (CNT) and $\mathrm{TiO}_{2}$.

The nanocomposites of PP with contents of 5 and $10 \mathrm{wt} \%$ (Figure 3e,f), showed signals corresponding to $\mathrm{PP}$ and $\mathrm{TiO}_{2}$ resin, and in $443 \mathrm{~cm}^{-1}$ a signal that corresponds to Ti-O bond was detected. The other signal that increases intensity in the nanocomposites with greater charge percentages ( 5 and $10 \%$ ) is the one corresponding to $\mathrm{CH}_{3}$, with values in the order of $1373 \mathrm{~cm}^{-1}$.

This coincides with results obtained by Hashing et al. in 2004, when preparing nanocomposites with PP and CNT by mechanical pulverization, where they obtained variation in the intensities of the 
signals at $1373 \mathrm{~cm}^{-1}$, attributing this result to that some PP chains are strongly bonded to CNT walls, in consequence to strong actions of cut, compression, and friction of mixing [37].

The FT-IR spectrum of neat PP processed at same conditions as nanocomposites shows a small signal in $1745 \mathrm{~cm}^{-1}$, which is related to its thermo-oxidative degradation and the formation of carbonyl groups. The presence of these carbonyl groups into range of 1810 to $1660 \mathrm{~cm}^{-1}$ [38] is reported in the literature. On the other hand, the FT-IR spectra nanocomposites do not show the signal in $1745 \mathrm{~cm}^{-1}$ which suggests that the NPs mix of $\mathrm{CNT}$ and $\mathrm{TiO}_{2}$ inhibits or reduces the thermo-oxidative degradation effects during processing of PP.

In this regard, it has been reported that the use of $\mathrm{TiO}_{2}$ as an additive reduces the thermal degradation of PP. When there is an increase of $\mathrm{TiO}_{2}$ concentration, the signals attributed to asymmetric and symmetric C-H stretching vibration (3000-2800 $\mathrm{cm}^{-1}$ ), exhibit an intensity rise, which can suggest an increase in thermal stability of PP. The absence of bands in the wave number range $3600-3200 \mathrm{~cm}^{-1}$ indicates that formation of hydroperoxides was not favored [39].

\subsection{Evaluation of Melt Flow Index (MFI)}

The results of the evaluation of melt flow index (MFI) for different samples are listed in Table 2. The MFI values suggest that the addition of nanoparticles increase the viscosity, as a result of the materials becoming less fluid after increasing the $\mathrm{CNT}$ and $\mathrm{TiO}_{2}$ content. The PP- $\mathrm{TiO}_{2} / \mathrm{CNT}-10$ nanocomposite showed greater viscosity increase $(0.24 \mathrm{MFI} / 10 \mathrm{~min})$, in comparison with the value shown by PP without charge $(0.76 \mathrm{~g} / 10 \mathrm{~min})$. The nanocharges have a high aspect ratio, which favors strong intermolecular interaction with the polymeric matrix; the adsorption of PP chains in the surface of nanocharges increases viscosity. These interactions increase the deformation resistance to hinder polymer flow in melted state, thereby making difficult or limiting the polymer flow in melted state [40].

Table 2. Flow index of the samples analyzed.

\begin{tabular}{cc}
\hline Sample & MFI (g/10 min) \\
\hline PP & 0.76 \\
PP-TiO $_{2} /$ CNT- 1 & 0.56 \\
PP-TiO $_{2} /$ CNT-5 & 0.40 \\
PP-TiO $_{2} /$ CNT-10 & 0.24 \\
\hline
\end{tabular}

\subsection{Thermogravimetric Analysis (TGA)}

To define thermal stability of nanocomposites, thermogravimetric analysis was performed. Figure 4 shows these results and it can be noted that materials have similar thermal behavior; the samples analyzed do not exhibited weight loss related to water adsorbed in surface materials. The first weight loss is in the range $358-500{ }^{\circ} \mathrm{C}$, this is attributed to breaking of chains existing in polypropylene structure [41]. 


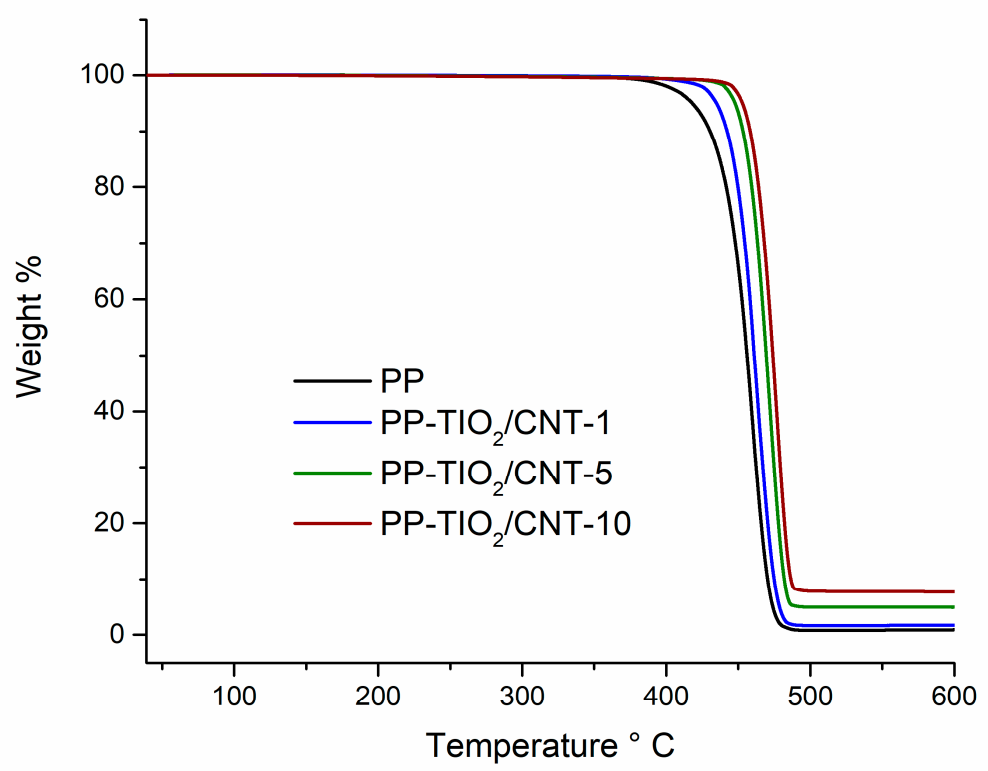

Figure 4. Thermogravimetric analysis of polypropylene (PP) and nanocomposites $\mathrm{PP}-\mathrm{TiO}_{2} / \mathrm{CNT}$ (carbon nanotubes).

The nanocomposites thermograms show that mass losses at $5 \mathrm{wt} \%$ and $50 \mathrm{wt} \%$ are detected at different temperatures in each nanocomposite (Table 3). In general, the temperatures $\mathrm{T}_{5 \%}$ and $\mathrm{T}_{50 \%}$ increased with the charges content in the nanocomposites. The PP- $\mathrm{TiO}_{2} / \mathrm{CNT}-10$ nanocomposite showed the highest temperature compared to nanocomposites with less nanocharge content. The $5 \mathrm{wt} \%$ decompositions for neat PP in PP-TiO $2 / C N T-1, \mathrm{PP}-\mathrm{TiO}_{2} / \mathrm{CNT}-5$, and $\mathrm{PP}-\mathrm{TiO}_{2} / \mathrm{CNT}-10$ occurred at 435,448 , and $454^{\circ} \mathrm{C}$, respectively. This means that the addition of charges increases the decomposition temperature in 18,31 , and $37^{\circ} \mathrm{C}$. Similar behavior was shown when the nanocomposites reached a $50 \mathrm{wt} \%$ of decomposition.

Table 3. Thermal properties of nanocomposite of polypropylene-carbon-nanotubes (PP- $\mathrm{TiO}_{2} / \mathrm{CNT}$ ).

\begin{tabular}{ccccc}
\hline Sample & $\mathbf{T}_{\mathbf{5 \%}}\left({ }^{\circ} \mathbf{C}\right)$ & $\mathbf{T}_{\mathbf{5 0} \%}\left({ }^{\circ} \mathbf{C}\right)$ & $\mathbf{T}_{\max }\left({ }^{\circ} \mathbf{C}\right)$ & Residue at $\mathbf{5 5 0}{ }^{\circ} \mathbf{C ~ ( \% )}$ \\
\hline $\mathrm{PP}$ & 417 & 454 & 459 & 0 \\
$\mathrm{PP}_{\mathrm{TiO}} / \mathrm{CNT}-1$ & 435 & 460 & 462 & 1.00 \\
$\mathrm{PP}_{\mathrm{TiO}} / \mathrm{CNT}-5$ & 448 & 469 & 472. & 4.92 \\
$\mathrm{PP}^{-\mathrm{TiO}_{2}} / \mathrm{CNT}-10$ & 454 & 474 & 475 & 8.02 \\
\hline
\end{tabular}

These results indicated that using $\mathrm{TiO}_{2}$ and CNT blend improves PP thermal stability; therefore, these combinations are a viable alternative to obtain flame retardant materials. Similar results have been reported when using $\mathrm{TiO}_{2}$ and $\mathrm{CNT}$ nanoparticles individually in polypropylene [42,43].

To define a comparison of maximum decomposition temperature $\left(\mathrm{T}_{\max }\right)$ the second derivative was used in TGA analysis. The values obtained in several formulations corroborate the difference of thermal stability between nanocomposites and PP without charge. The nanocomposites showed greater $\mathrm{T}_{\max }$, the PP- $\mathrm{TiO}_{2} / \mathrm{CNT}-10$ sample increased its $\mathrm{T}_{\max }$ in $16{ }^{\circ} \mathrm{C}$ above pure $\mathrm{PP}$.

The increase in starting decomposition temperature can be attributed to the increase in the addition strength in the PP interface and the $\mathrm{CNT}$ and $\mathrm{TiO}_{2}$ nanoparticles. When proper interface interaction exists, the particles are able to restrain the movement of polymer chain, making it more difficult that the breaking of the polymer chains occurs at lower temperature. In consequence, the degradation temperature of nanocomposite is shifted to a higher temperature [44].

Other element to consider when improving thermal stability of nanocomposites is the transport barrier effect of the mass of the CNT hollow structure, and these structures can trap the free radicals generated during PP thermal $[45,46]$. 


\subsection{Differential Scan Calorimetry (DSC) Analysis}

By DSC analysis, the melting temperature $T_{m}$, crystallization temperature $T c$ and degree of crystallinity $X_{c}$, were derived from endothermic and exothermic peak temperatures. These thermograms are shown in Figures 5 and 6.

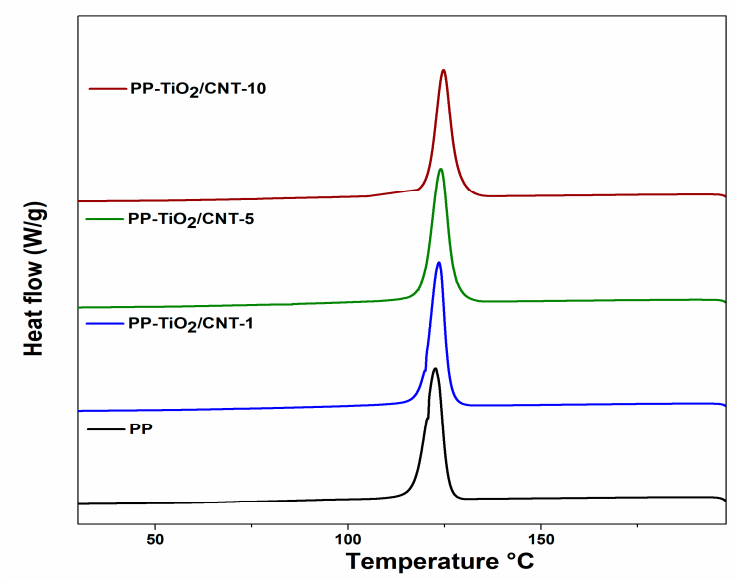

Figure 5. Differential scanning calorimetry (DSC) crystallization exotherms of pure polypropylene (PP) and $\mathrm{PP}-\mathrm{TiO}_{2} / \mathrm{CNT}$ (carbon nanotubes) $(1,5,10 \%)$.

The DSC analyses reported that Tc and Tm increase gradually with the increase of nanoparticles $\left(\mathrm{TiO}_{2}\right.$ and $\left.\mathrm{CNT}\right)$ in the $\mathrm{PP}$, reaching temperatures above $122^{\circ} \mathrm{C}$ and $157^{\circ} \mathrm{C}$, respectively.

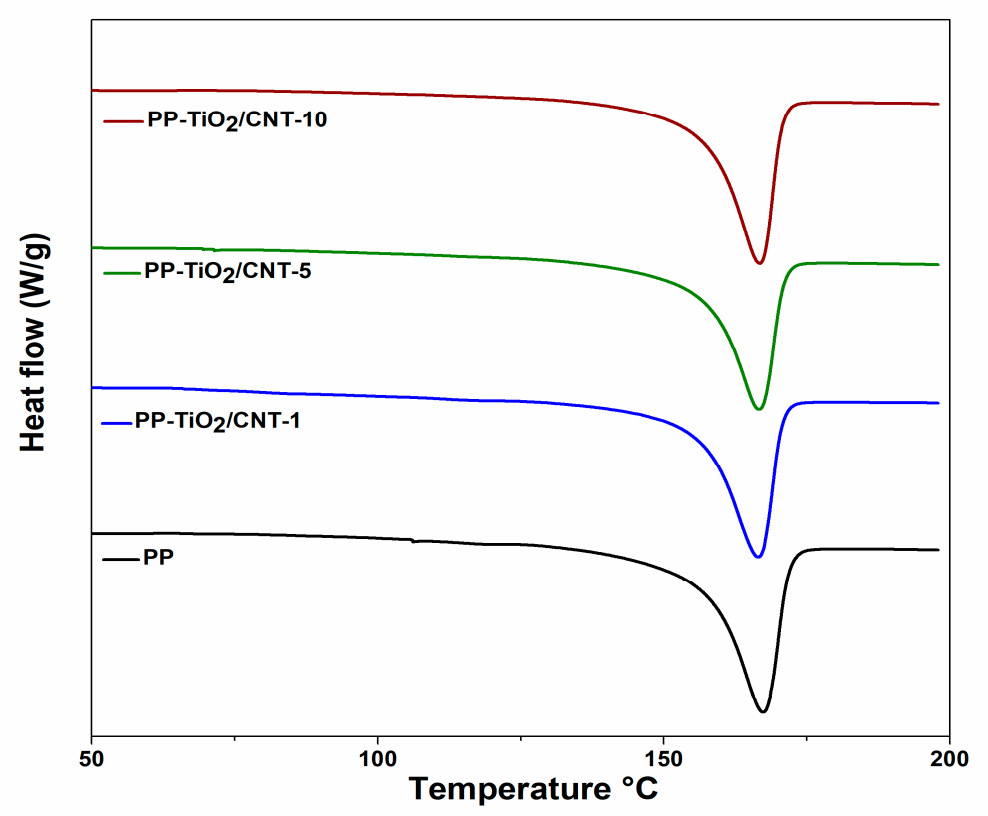

Figure 6. Differential scanning calorimetry (DSC) fusion endotherms of pure polypropylene (PP) and $\mathrm{PP}^{-\mathrm{TiO}_{2}} / \mathrm{CNT}$ (carbon nanotubes) $(1,5,10 \%)$.

The crystallization process can be noted in the DSC curves; in Table 4 is the summary of fusion enthalpies, crystallization, and degree of crystallinity calculated with Equation (1), for each of the studied materials. The presence of nanocharges affects PP crystallinity, the fusion peaks are narrow in comparison to peak from neat PP, $\mathrm{X}_{\mathrm{c}}$ decreases in the extent the nanocharges content (CNT and $\mathrm{TiO}_{2}$ ) increases, for nanocomposite with greater content of charges $X_{\mathrm{c}}$ decreased $3.38 \mathrm{wt} \%$, and this behavior can be related to the agglomeration of particles. Some reports indicate that formation 
of nanocomposites with high content of CNT can induce effects of topologic confinement that can eventually result in reduction of nucleation kinetics and crystallization [47-50].

Table 4. Differential scanning calorimetry (DSC) date for polypropylene (PP) and nanocomposites $\mathrm{PP}^{-\mathrm{TiO}_{2}} / \mathrm{CNT}$ (carbon nanotubes) (1, 5 y $\left.10 \%\right)$.

\begin{tabular}{ccccc}
\hline Nanocomposite & $\mathbf{T}_{\mathbf{m}}\left({ }^{\circ} \mathbf{C}\right)$ & Enthalpy of Fusion $(\mathbf{J} / \mathbf{g})$ & Enthalpy of Crystallization $(\mathbf{J} / \mathbf{g})$ & $\boldsymbol{X}_{\boldsymbol{c}}(\%)$ \\
\hline $\mathrm{PP}$ & 156.93 & 95.82 & 93.72 & 45.84 \\
$\mathrm{PP}_{\mathrm{TiO}} / \mathrm{CNT}-1$ & 156.16 & 93.45 & 95.35 & 44.71 \\
$\mathrm{PP}_{\mathrm{TiO}} / \mathrm{CNT}-5$ & 157.14 & 91.06 & 92.82 & 43.56 \\
$\mathrm{PP}^{-\mathrm{TiO}_{2}} / \mathrm{CNT}-10$ & 157.07 & 88.75 & 93.63 & 42.46 \\
\hline
\end{tabular}

In 2015, Zhang et al. [51], in their research with PP and CNT nanocomposites, suggest that variation of crystallization temperature is strongly related to different functions that charges have during PP crystallization.

The effect caused by $\mathrm{CNT}$ and $\mathrm{TiO}_{2}$ nanoparticles in the PP matrix is known. Some reports are contradictory because the physicochemical characteristics of the nanoparticles are not always the same, so the aggregation and dispersion in semicrystalline polymers is different. On the other hand, the final properties of most semicrystalline polymers depend on the microstructures, which are mainly affected by crystallization [52]. The polymer crystallization may be intimately related to the type of nanoparticle and concentration, dispersion state, aspect ratio, crystallization conditions, and so on. [53-57] All these conditions can explain the contradictory results that have been reported; in the $\mathrm{PP}-\mathrm{TiO}_{2} / \mathrm{CNT}$ nanocomposites, the presence of two nanocharges type of blend increases the adverse effects.

The results obtained for the $\mathrm{PP}-\mathrm{TiO}_{2} / \mathrm{CNT}$ nanocomposites are expected and they coincide with what is reported in literature, where the effect of $\mathrm{CNT}$ and $\mathrm{TiO}_{2}$ nanoparticles individually has been studied. For example, several reports show that CNT accelerates PP crystallization only at contents less than $0.5 \mathrm{wt} \%$ due to strong heterogeneous nucleation effect of the CNTs in the PP. When the concentration increases, the formation of aggregates is favored, and the heterogeneous nucleating efficiency of the individual CNTs is lowered [58].

The $\mathrm{PP} / \mathrm{TiO}_{2}$ nanocomposites have similar behavior independent of size and shape of nanoparticles, $X_{c}$ increases with contents of $\mathrm{TiO}_{2}$ of $0.5-2 \mathrm{wt} \%$, when the content increases between $3-4 \mathrm{wt} \%$, decreases it, but the value is similar to that shown for PP [22].

In summary, the high $\mathrm{CNT}$ content decreases crystallinity, whereas $\mathrm{TiO}_{2}$ increases the crystallinity, even at high contents of $\sim 2 \%$. The nanocomposites of $\mathrm{PP} / \mathrm{TiO}_{2} / \mathrm{CNT}$ have a ratio of $\mathrm{CNT} / \mathrm{TiO}_{2}$ of 2:1. Therefore, the expected effect for CNT on the PP matrix is more predominant. According to Table 4, a decrease was detected in $\mathrm{Xc}_{\mathrm{c}}$ and it decreases in the extent of CNT content increases.

\subsection{Electron Scan Microscopy}

Figure 7 shows SEM micrographs of PP-TiO $2 / C N T-1, \mathrm{PP}_{2} \mathrm{TiO}_{2} / \mathrm{CNT}-5$, and $\mathrm{PP}-\mathrm{TiO}_{2} / \mathrm{CNT}-10$ nanocomposites. In these SEM images, the presence of $\mathrm{CNT}$ and $\mathrm{TiO}_{2}$ nanoparticles can be verified. All micrographs exhibited two zones with different nanoparticles agglomeration, in zone 1 (Supplementary Materials) agglomerates can be observed containing both nanoparticles and their contact between them. Also, the amount of agglomerates increases with the increase in the $\mathrm{CNT}$ and $\mathrm{TiO}_{2}$ content. The zone 2 showed less agglomeration and it was noted that both nanoparticles are embedded within PP matrix (Figure 7a-c). In these zones, it is difficult to define if $\mathrm{CNT}_{\text {and }} \mathrm{TiO}_{2}$ nanoparticles are in contact. In the micrography of $\mathrm{PP}-\mathrm{TiO}_{2} / \mathrm{CNT}-10$ nanocomposite with greater content of nanoparticles (Figure 7c), small agglomerates were detected where there is contact between $\mathrm{TiO}_{2}$ nanoparticles. It is worth to mention that processing conditions of nanocomposites causes coalescence between $\mathrm{TiO}_{2}$ nanoparticles and in some cases the spherical shape it is not well defined; similar results were previously reported [59]. The coalescence is not exclusive to $\mathrm{TiO}_{2} \mathrm{NPs}$. The spherical copper nanoparticles (Cu NPs), with an 
average size of $21 \mathrm{~nm}$ when they are processed to obtain Nylon 6/Cu nanocomposites, increased their size and formed aggregates in form of wire [60].

The increase in viscosity caused coalescence of the $\mathrm{TiO}_{2} \mathrm{NPs}$, the PP-TiO$/ 2 / C N T-10$ had an average particle size of $200 \mathrm{~nm}$, and the nanocomposites with 1 and $5 \mathrm{wt} \%$ of NPs had an average particle size of $557 \mathrm{~nm}$ and $286 \mathrm{~nm}$, respectively (Supplementary Materials Figures S1-S3).
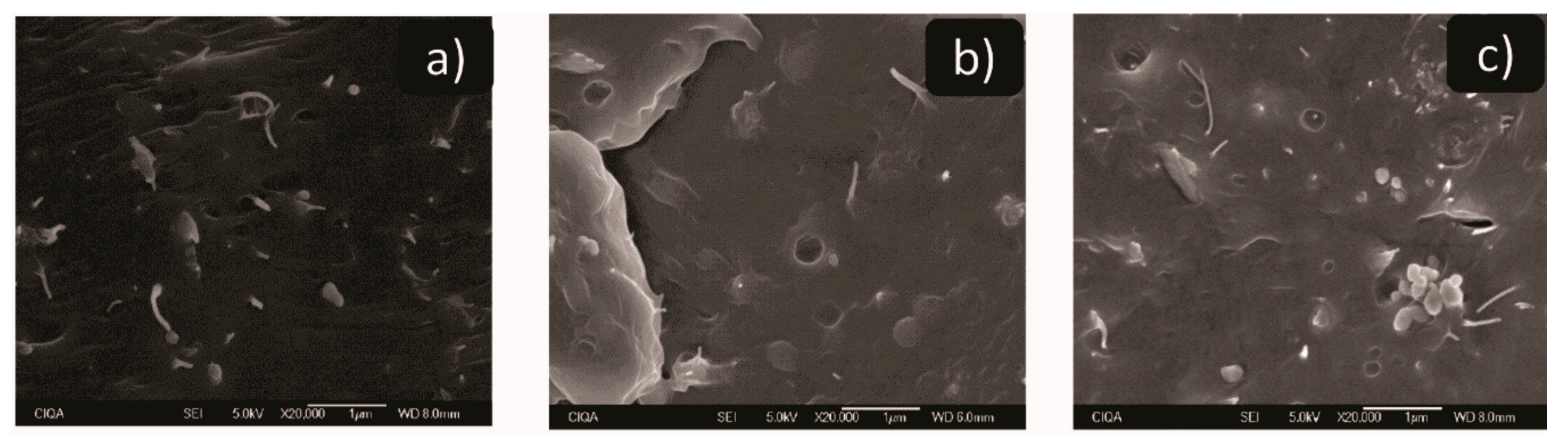

Figure 7. SEM micrographs of nanocomposites. (a) polypropylene-carbon-nanotubes ( $\left.\mathrm{PP}-\mathrm{TiO}_{2} / \mathrm{CNT}-1\right)$,

(b) $\mathrm{PP}^{-\mathrm{TiO}_{2}} / \mathrm{CNT}-5$ and (c) PP-TiO $2 / \mathrm{CNT}-10$.

In some of the micrographs, a series of cavities or voids can be observed in the polymeric matrix. This can be due to the fact that the extrusion process of the particles of greater size is sent against the next material, impacting and forming a track or trail [61].

\subsection{Electrical Conductivity}

The electric resistance of nanocomposites decreases to the extent the nanoparticles content increases; this effect was only significant in the PP-TiO $2 / C N T-10$ nanocomposite. With the addition of $10 \%$ of nanoparticles, the electrical conductivity increased 6 times with regards to pure polypropylene. Table 5 lists the obtained values of electrical resistance and calculated electrical conductivity. The lack of electrical conductivity in nanocomposites with 1 and $5 \mathrm{wt} \%$ can be explained by an inefficient dispersion of nanoparticles, and this coincides with SEM analysis. Another possible explanation can be found in the amount of PP that can be bonded to nanoparticles. The adherence of polymer chains to nanoparticles surface prevents electrons flow, and it is known that thermal treatments can improve the electrical conductivity, due to destruction of crystalline phase of existent polymer in the surface [62].

The electrical conductivity of PP/CNT nanocomposites has been deeply studied and it is known that nanocomposites with content of CNT of $10 \mathrm{wt} \%$ can have resistivity of up to $10^{2} \Omega / \mathrm{sq}$ [63].

There are few studies about electrical properties of $\mathrm{PP} / \mathrm{TiO}_{2}$ nanocomposites. To our knowledge, there is only one study about this, and is reported that with the increase in volume content of titanium-dioxide nanoparticles, the value of dielectric permittivity of nanocomposites also increases, and after some point it starts to decrease. The specific resistance of nanocomposites depends on temperature and it was detected that at $116.9{ }^{\circ} \mathrm{C}$ the electrical properties of nanocomposite show significant improvement [64].

Table 5. Electrical properties of polypropylene (PP) and $\mathrm{PP}-\mathrm{TiO}_{2} / \mathrm{CNT}$ (carbon-nanotubes) nanocomposites.

\begin{tabular}{|c|c|c|c|}
\hline Sample & $\begin{array}{c}\text { Surface Resistance } \\
\Omega / \mathrm{sq}\end{array}$ & $\begin{array}{l}\text { Volumetric Resistance } \\
\Omega \mathrm{cm}\end{array}$ & $\begin{array}{l}\text { Electric Conductivity } \\
\mathrm{S} / \mathrm{m}\end{array}$ \\
\hline PP & $2.35 \times 10^{13}$ & $1 \times 10^{18}$ & $1 \times 10^{-18}$ \\
\hline PP-TiO $2 / C N T-1$ & $6 \times 10^{16}$ & $3 \times 10^{17}$ & $3.0 \times 10^{-18}$ \\
\hline PP-TiO $2 / C N T-5$ & $3 \times 10^{12}$ & $5 \times 10^{16}$ & $2.0 \times 10^{-17}$ \\
\hline 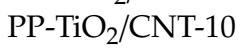 & $6.5 \times 10^{9}$ & $7.2 \times 10^{9}$ & $1.4 \times 10^{-10}$ \\
\hline
\end{tabular}




\subsection{Mechanical Properties}

The results of mechanical tests are listed in Table 6, where tensile strength, percentage of nominal deformation to rupture, and Young's modulus values for nanocomposites can be noted. In this analysis, it was observed PP without charge presented a tensile strength of $23.93 \mathrm{MPa}$, while the $\mathrm{PP}-\mathrm{TiO}_{2} / \mathrm{CNT}$ nanocomposites showed low values, which decreases in the extent the nanoparticles content is increased. These values coincide with the degree of crystallinity (Table 4); in consequence, the decrease of rigidity of matrix of PP is favored.

Table 6. Tensile properties of polypropylene (PP) and $\mathrm{PP}-\mathrm{TiO}_{2} / \mathrm{CNT}$ (carbon nanotubes) nanocomposites.

\begin{tabular}{ccccc}
\hline Sample & $\mathbf{X c}$ & $\begin{array}{c}\text { Tensile Strength } \\
\text { (MPa) }\end{array}$ & $\begin{array}{c}\text { Nominal Strain at } \\
\text { Break (\%) }\end{array}$ & $\begin{array}{c}\text { Young's Modulus } \\
\text { (MPa) }\end{array}$ \\
\hline $\mathrm{PP}$ & 56.36 & $23.93 \pm 0.12$ & 53.37 & $971.57 \pm 29.1$ \\
$\mathrm{PP}_{\mathrm{TiO}} / \mathrm{CNT}-1$ & 54.97 & $23.93 \pm 0.19$ & 45.78 & $894.98 \pm 27.1$ \\
$\mathrm{PP}_{\mathrm{TiO}} / \mathrm{CNT}-5$ & 53.56 & $23.32 \pm 0.08$ & 33.24 & $961.28 \pm 31.0$ \\
$\mathrm{PP}^{-\mathrm{TiO}_{2}}$ /CNT-10 & 52.20 & $22.75 \pm 0.37$ & 22.28 & $1077.44 \pm 26.2$ \\
\hline
\end{tabular}

For the nominal percentage at the breaking the observed behavior is similar, such effect is due to the fact that nanotubes particles obstruct the movement of PP chains, reducing rigidity. Young's modulus of $\mathrm{PP}^{-\mathrm{TiO}_{2}} / \mathrm{CNT}-10$ nanocomposite showed an increase of $18.3 \%$ with regards PP without charges. This was the only case where it was observed that nanoparticles cause higher rigidity and hardness in the PP matrix. It has been reported that adding CNT in polymers will strengthen material, if there is an efficient dispersion [65]

The decrease of Young's modulus when increasing charges content is explained by inefficient dispersion of charges, since the agglomerates present in poorly dispersed composite cause cracks to initiate and easily propagate in polymeric matrix [66]. As noted previously, the $\mathrm{TiO}_{2}$ nanoparticles tend to coalesce, increasing their size and changing shape. This process seems to be more significant when charges concentrates are lower ( 1 and $5 \%)$. This behavior can be attributed to the increase of viscosity with the nanoparticles' concentration. For low viscosity, the $\mathrm{TiO}_{2} \mathrm{NPs}$ are able to move in the matrix and aggregates, whereas at high concentrations the viscosity is higher and the aggregation is limited by slightly mobility of the nanoparticles.

\subsection{Calorimetric Cone}

To analyze combustion processes, in real time assessment of nanocomposites the cone calorimetry method was used. Heat release rate (HRR) and its maximum value (PHRR) were some of the parameters obtained in this study.

The heat release rate curves of the $\mathrm{PP}-\mathrm{TiO}_{2}-\mathrm{CNT}$ nanocomposite are shown in Figure 8. These results showed essentially a similar behavior, the maximum value of heat release rate (PHRR) for PP without charge and $\mathrm{PP}-\mathrm{TiO}_{2} / \mathrm{CNT}-1$ nanocomposite were of 1529.53 and $1593.83 \mathrm{~kW} / \mathrm{m}^{2}$ respectively, which means that there is no difference between pure PP and nanocomposite with low load percentages (1\%). In contrast, for PP-TiO $/$ /CNT- 5 and $\mathrm{TiO}_{2} / \mathrm{CNT}-10$ nanocomposites, a decrease was noted in $\mathrm{PHHR}$ and total heat release rate (THR) values, which indicates that materials have less flame propagation and better resistance to fire. The minimum values of PHHR that could be obtained were of $1058.49 \mathrm{~kW} / \mathrm{m}^{2}$ for PP-TiO $2 /$ CNT-5 and of $1079.94 \mathrm{~kW} / \mathrm{m}^{2}$ for $\mathrm{PP}^{-\mathrm{TiO}_{2}} / \mathrm{CNT}-10$. 

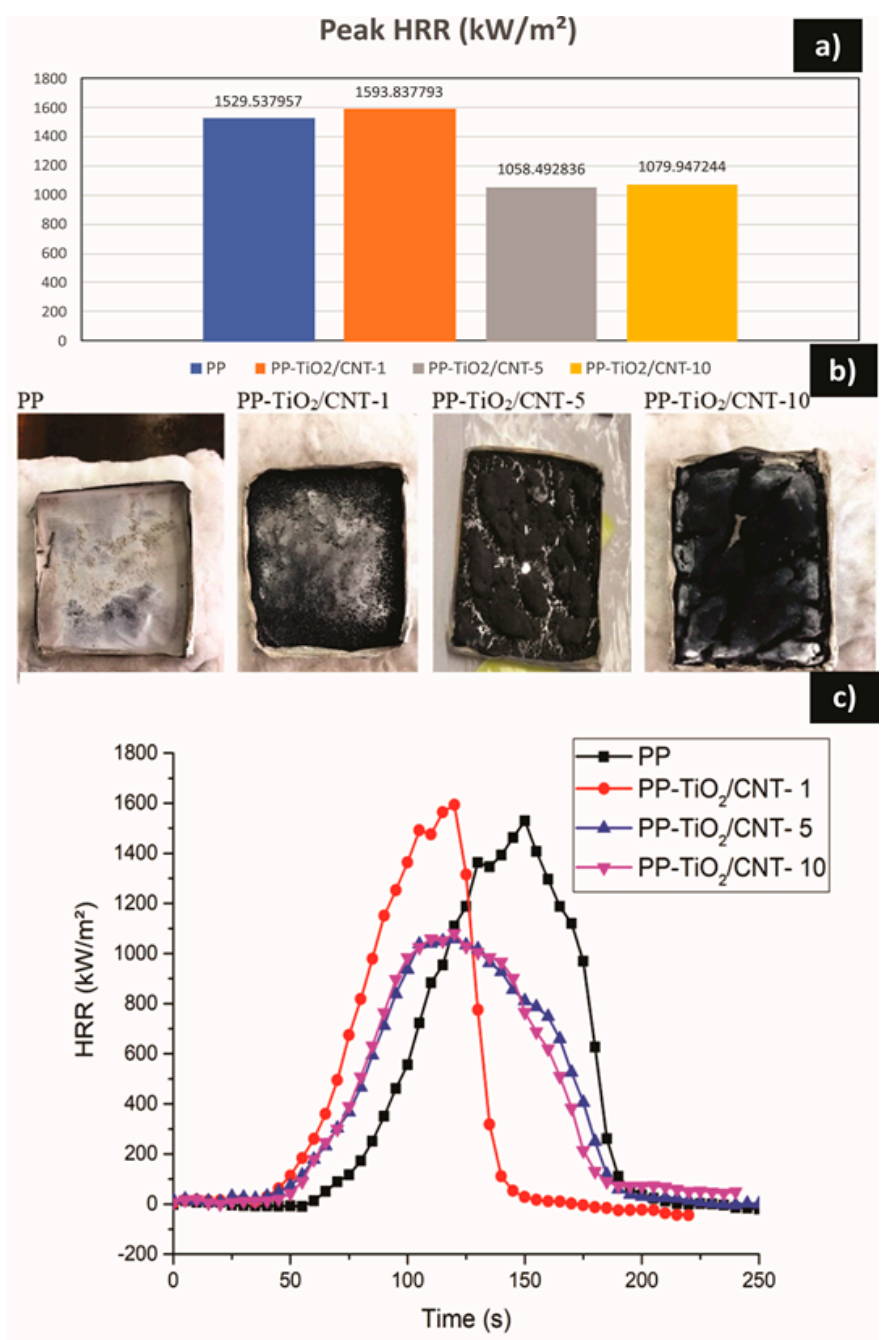

Figure 8. Calorimetric measurements (a) Comparison of the peaks of the heat release rate (HRR), (b) Photographs of residual material after the cone calorimetric test (c) HRR curves for the results.

Table 7 lists data of calorimetric cone, where it was noted that the total heat release rate (THR) reduced when increasing the particles content to 5 and $10 \% \mathrm{wt}$. Also, there are listed the wt $\%$ of residues obtained after flame-retardant assessment. The number of residues increases dramatically when the nanoparticles content increases. For PP-TiO $2 / C N T-10$ nanocomposite, the obtained residues were $91.9 \%$. In Figure $8 b$ ) the residues appearance can be observed. For the case of $\mathrm{PP}-\mathrm{TiO}_{2} / \mathrm{CNT}-1$, it was noted that there was a small amount of scattered dust, while for $\mathrm{PP}_{-} \mathrm{TiO}_{2} / \mathrm{CNT}-5$ y TiO $2 / \mathrm{CNT}-10 \mathrm{a}$ semi-continuous phase that suggests a good distribution of nanocharges in polypropylene matrix was noted. In addition, during the ignition a network forms between nanoparticles and degradation product of PP, and the new materials can have enough resistance to flame in order to avoid complete ignition. A similar explanation was obtained by studying the flammability properties of the $\mathrm{PP} / z$ zeolite/CNT nanocomposite, where it was proposed to form a protective layer with a continuous network structure that provides the flame-retardant characteristic of polymeric nanocomposites [67]. 
Table 7. Data of the calorimetric cone test of the samples analyzed.

\begin{tabular}{cccc}
\hline Sample & Peak HRR $\mathbf{( k W / \mathbf { m } ^ { 2 } )}$ & THR $\left.\mathbf{( M J} / \mathbf{m}^{2}\right)$ & Residue $\mathbf{( \% )}$ \\
\hline PP & 1529.53 & 66.42 & 0.09 \\
$\mathrm{PP}-T i O_{2} / \mathrm{CNT}-1$ & 1593.83 & 65.91 & 34.3 \\
$\mathrm{PP}-T i O_{2} / \mathrm{CNT}-5$ & 1058.49 & 43.49 & 88.4 \\
$\mathrm{PP}^{-\mathrm{TiO}_{2}}$ /CNT-10 & 1079.94 & 44.06 & 91.9 \\
\hline
\end{tabular}

Results coincide with other studies, for example, $\mathrm{PP} / \mathrm{CNT}$ nanocomposites are considered to be flame-retardant materials and even more effective than $\mathrm{PP} /$ clay nanocomposites. The combination of $\mathrm{TiO}_{2}$ and $\mathrm{CNT}$ to obtain anti-flame additives can be a good idea, because $\mathrm{TiO}_{2}$ has a high decomposition temperature $\left(700{ }^{\circ} \mathrm{C}-800{ }^{\circ} \mathrm{C}\right)$ and an oxygen index of 29 and has also been widely used as an anti-flame additive alone or in combination with other additives [5]. Despite the above, its usage, like flame-retardant in polyamides, has been technically questionable [68].

In our study, the CNT and $\mathrm{TiO}_{2}$ blends lead to obtaining nanocomposites with acceptable flame-retardant properties, but more detailed studies can be required to optimize formulation and to explain its possible mechanism.

\section{Conclusions}

The $\mathrm{PP}-\mathrm{TiO}_{2} / \mathrm{CNT}$ nanocomposites was obtained by the melt mixing method using a mixture of nanoparticles $\mathrm{TiO}_{2}$ and CNT, with contents of 1,5 , and $10 \mathrm{wt} \%$. The thermal stability of the nanocomposites increased when increasing the content of the NPs, for example, for $\mathrm{PP}_{-} \mathrm{TiO}_{2} / \mathrm{CNT}-10$, its maximum degradation temperature increased $16{ }^{\circ} \mathrm{C}$ with respect to the pure PP. In addition, the thermo-oxidative stability of the material was improved and confirmed by the lack of signals of the carbonyl group in FTIR spectrum. The degree of crystallinity decreased with a high content of NPs. This effect was also reflected in a slight decrease in mechanical properties, and only an in increase in the Young's modulus of $10 \%$ to $\mathrm{PP}-\mathrm{TiO}_{2} / \mathrm{CNT}-10$ was observed.

The electrical conductivity of $\mathrm{PP}-\mathrm{TiO}_{2} / \mathrm{CNT}-10$ nanocomposite was improved by eight orders of magnitude with respect to the pure PP; nanocomposites with low content do not have significant changes.

The melt flow index (MFI) of the nanocomposites decreased with the number of NPs, and the nanocomposites with 1,5 , and $10 \mathrm{wt} \%$ gave an MFI of $0.56,0.40$, and $0.24(\mathrm{~g} / 10 \mathrm{~min})$ respectively. The conditions of the melt processing and the increase in the viscosity caused coalescence of the $\mathrm{TiO}_{2} \mathrm{NPs}$. This conducted to different average particle size in each nanocomposite.

Finally, the effect of flame retardancy was confirmed by a significant decrease of the peak HRR in the nanocomposites PP-TiO $2 / C N T-5$ and PP-TiO $2 / C N T-10$, and besides this, $\mathrm{PP}_{2}-\mathrm{TiO}_{2} / \mathrm{CNT}-10$ presented a content of residual carbon of $91.9 \%$ after ignition.

Supplementary Materials: The following are available online at http:/www.mdpi.com/2073-4360/11/7/1204/s1. Figure S1. Morphology nanocomposite PP-TiO $2 / C N T-1$ analyzed by SEM, histogram of $\mathrm{TiO}_{2}$ particle. Figure S2. Morphology nanocomposite $\mathrm{PP}-\mathrm{TiO}_{2} / \mathrm{CNT}-5$ analyzed by SEM, histogram of $\mathrm{TiO}_{2}$ particle. Figure S3. Morphology nanocomposite $\mathrm{PP}-\mathrm{TiO}_{2} / \mathrm{CNT}-10$ analyzed by SEM, histogram of $\mathrm{TiO}_{2}$ particle.

Author Contributions: C.C.A. performed experiments on nanocomposite $\mathrm{PP}-\mathrm{TiO}_{2} / \mathrm{CNT}$. P.R.R. analyzed the data and contributed to the discussions on DRX and TGA, M.A.G. analyzed the data and contributed to the discussions on FT-IR and Electrical conductivity, V.C.D. and L.M.L. performed experiments and analyzed calorimetric cone, C.A.O. and G.C.P. provided technical discussions and reviewed and contributed to the final revised manuscript. M.P.A. performed the mechanical properties, Z.Q.J. SEM analysis.

Funding: Financial support from project Tlax-2018-01-01-43129 by CONACYT.

Acknowledgments: The authors kindly acknowledge the scholarship postdoctoral (387368) provided by CONACYT-Mexico. The authors are also grateful Jesús Angel Cepeda Garza, Jesús Alejandro Espinosa Muñoz, Ma. Guadalupe Méndez Padilla and Adán Herrera Guerrero, for their technical support.

Conflicts of Interest: The authors declare no conflict of interest. 


\section{References}

1. Panzino, F.; Piza, A.; Pociello, N.; García, J.J.; Luaces, C.; Pou, J. Estudio multicéntrico sobre factores de riesgo de lesiones en accidentes de automóvil. In Anales de Pediatría; Elsevier Doyma: Amsterdam, The Netherlands, 2009; Volume 71, pp. 25-30. [CrossRef]

2. Adanur, S. Polymers and Fiber. Wellington Sears Handbook of Industrial Textiles; Routledge: New York, NY, USA, 2017; Volume 2, pp. 12-37. [CrossRef]

3. Kiliaris, P.; Papaspyrides, C.D. Polymer/layered silicate (clay) nanocomposites: An overview of flame retardancy. Prog. Polym. Sci. 2010, 35, 902-958. [CrossRef]

4. Thomas, N.L. Zinc compounds as flame retardants and smoke suppressants for rigid PVC. Plast. Rubber Compos. 2003, 32, 413-419. [CrossRef]

5. Lam, Y.L.; Kan, C.W.; Yuen, C.W.M. Effect of titanium dioxide on the flame-retardant finishing of cotton fabric. J. Appl. Polym. Sci. 2011, 121, 267-278. [CrossRef]

6. Dittrich, B.; Wartig, K.; Hofmann, D.; Mülhaupt, R.; Schartel, B. Carbon black, multiwall carbon nanotubes, expanded graphite and functionalized graphene flame retarded polypropylene nanocomposites. Polym. Adv. Technol. 2013, 24, 916-926. [CrossRef]

7. Mubarak, Y.A.; Abbadi, F.O.; Tobgy, A.H. Effect of iron oxide nanoparticles on the morphological properties of isotactic polypropylene. J. Appl. Polym. Sci. 2010, 115, 3423-3433. [CrossRef]

8. Hufenbach, W.; Böhm, R.; Thieme, M.; Winkler, A.; Mäder, E.; Rausch, J.; Schade, M. Polypropylene/glass fibre 3D-textile reinforced composites for automotive applications. Mater. Des. 2011, 32, 1468-1476. [CrossRef]

9. Ayrilmis, N.; Jarusombuti, S.; Fueangvivat, V.; Bauchongkol, P.; White, R.H. Coir fiber reinforced polypropylene composite panel for automotive interior applications. Fibers Polym. 2011, 12, 919. [CrossRef]

10. Saujanya, C.; Radhakrishnan, S. Structure development and crystallization behaviour of PP/nanoparticulate composite. Polymer 2001, 42, 6723-6731. [CrossRef]

11. Mishra, S.; Sonawane, S.H.; Singh, R.P.; Bendale, A.; Patil, K. Effect of nano- $\mathrm{Mg}(\mathrm{OH})_{2}$ on the mechanical and flame-Retarding properties of polypropylene composites. J. Appl. Polym. Sci. 2004, 94, 116-122. [CrossRef]

12. Alexandre, M.; Dubois, P. Polymer-layered silicate nanocomposites: Preparation, properties and uses of a new class of materials. Mater. Sci. Eng. R 2000, 28, 1-63. [CrossRef]

13. Demir, H.; Arkis, E.; Balköse, D.; Ülkü, S. Synergistic effect of natural zeolites on flame retardant additives. Polym. Degrad. Stab. 2005, 89, 478-483. [CrossRef]

14. Ke, C.H.; Li, J.; Fang, K.; Zhu, K.; Zhu, J.; Yan, Q.; Wang, Y. Synergistic effect between a novel hyperbranched charring agent and ammonium polyphosphate on the flame retardant and anti-dripping properties of polylactide. Polym. Degrad. Stab. 2010, 95, 763-770. [CrossRef]

15. Kausar, A.; Rafique, I.; Muhammad, B. Review of Applications of Polymer/Carbon nanotube and Epoxy/CNT Composites. Polym. Plast. Technol. Eng. 2016, 55, 1167-1191. [CrossRef]

16. Lau, A.K.T.; Hui, D. The revolutionary creation of new advanced materials-carbon nanotube composites. Compos. Part B Eng. 2002, 33, 263-277. [CrossRef]

17. Kashiwagi, T.; Grulke, E.; Hilding, J.; Groth, K.; Harris, R.; Butler, K.; Douglas, J. Thermal and flammability properties of polypropylene/carbon nanotube nanocomposites. Polymer 2004, 45, 4227-4239. [CrossRef]

18. Antunes, M.; Mudarra, M.; Velasco, J.I. Broad-band electrical conductivity of carbon nanofibre-reinforced polypropylene foams. Carbon 2011, 49, 708-717. [CrossRef]

19. Seo, M.K.; Park, S. Electrical resistivity and rheological behaviors of carbon nanotubes-filled polypropylene composites. Chem. Phys. Lett. 2004, 395, 44-48. [CrossRef]

20. Avalos, F.; Ramos, L.F.; Ramirez, E.; Sanchez, S.; Mendez, J.; Zitzumbo, R. Nucleating effect of carbón nanoparticles and their influence on the thermal and chemical stability of polypropylene. J. Nanomater. 2012, 2012, 104. [CrossRef]

21. Kurahatti, R.V.; Surendranathan, A.O.; Kori, S.A.; Singh, N.; Kumar, A.R.; Srivastava, S. Defence applications of polymer nanocomposites. Def. Sci. J. 2010, 60, 551-563. [CrossRef]

22. Aydemir, D.; Uzun, G.; Gumus, H.; Yildiz, S.; Gumus, S.; Bardak, T.; Gunduz, G. Nanocomposites of polypropylene/nano titanium dioxide: Effect of loading rates of nano titanium dioxide. Mater. Sci. 2016, 22, 364-369. [CrossRef]

23. Esthappan, S.K.; Kuttappan, S.K.; Joseph, R. Thermal and mechanical properties of polypropylene/titanium dioxide nanocomposite fibers. Mater. Des. 2012, 37, 537-542. [CrossRef] 
24. El-dessouky, H.M.; Lawrence, C.A. Nanoparticles dispersion in processing functionalized $\mathrm{PP} / \mathrm{TiO}_{2}$ nanocomposite: Distribution and properties. J. Nanopart. Res. 2011, 13, 1115-1124. [CrossRef]

25. Cassagnau, P.; Legare, V.; Fenouillot, F. Reactive processing of thermoplastic polymer: A review of the fundamental aspect. Int. Polym. Process. 2007, 22, 218-258. [CrossRef]

26. Chiamori, H.C.; Brown, J.W.; Adhiprakasha, E.V.; Hantsoo, E.T.; Straalsund, J.B.; Melosh, N.A.; Pruitt, B.L. Suspension of nanoparticles in SU-8: Processing and characterization of nanocomposite polymers. Microelectron. J. 2008, 39, 228-236. [CrossRef]

27. Logakis, E.; Pollatos, E.; Pandis, C.; Peoglos, V.; Zuburtikis, I.; Delides, C.G.; Vatalis, A.; Gjoka, M.; Syskakis, E.; Viras, K.; et al. Structure-property relationships in isotactic polypropylene/multi-walled carbon nanotubes nanocomposites. Compos. Sci. Technol. 2010, 70, 328-335. [CrossRef]

28. Crossman, R.A. Conductive composites past, present, and future. Polym. Eng. Sci. 1985, 25, 507-513. [CrossRef]

29. Wang, S.; Abdellah, A.; Shaoyun, G.; Chuanxi, X. Preparation of microporous polypropylene/titanium dioxide composite membranes with enhanced electrolyte uptake capability via melt extruding and stretching. Polymers 2017, 9, 110. [CrossRef]

30. Bahloul, W.; Walid, B.; Flavien, M.; Veronique, B.L.; Philippe, C. Structural characterisation and antibacterial activity of $\mathrm{PP} / \mathrm{TiO}_{2}$ nanocomposites prepared by an insitu sol-gel method. Mater. Chem. Phys. 2012, 134, 399-406. [CrossRef]

31. Wang, S.; Zhang, J. Effect of nucleating agent on the crystallization behavior, crystal form and solar reflectance of polypropylene. Sol. Energy Mater. Sol. Cells 2013, 117, 577-584. [CrossRef]

32. Zohrevand, A.; Ajji, A.; Mighri, F. Morphology and properties of highly filled $\mathrm{iPP} / \mathrm{TiO}_{2}$ nanocomposites. Polym. Eng. Sci. 2014, 54, 874-886. [CrossRef]

33. Liu, Z.; Jian, Z.; Fang, J.; Xu, X.; Zhu, X.; Wu, S. Low-temperature reverse microemulsion synthesis, characterization, and photocatalytic performance of nanocrystalline titanium dioxide. Int. J. Photoenergy 2011, 2012, 702503. [CrossRef]

34. Leon, A.; Reuquen, P.; Garin, C.; Segura, R.; Vargas, P.; Zapata, P.; Orihuela, P. FTIR and Raman characterization of $\mathrm{TiO}_{2}$ nanoparticles coated with polyethylene glycol as carrier for 2-methoxyestradiol. Appl. Sci. 2017, 7, 49. [CrossRef]

35. Nguyen, V.H.; Shim, J.J. Green synthesis and characterization of carbon nanotubes/polyaniline nanocomposites. J. Spectrosc. 2015, 2015, 297804. [CrossRef]

36. Yildrim, A.; Seckin, T. In situ preparation of polyether amine functionalized MWCNT nanofiller as reinforcing agents. Adv. Mater. Sci. Eng. 2014, 2014, 356920. [CrossRef]

37. Xia, H.; Wang, Q.; Li, K.; Hu, G.H. Preparation of polypropylene/carbon nanotube composite powder with a solid-state mechanochemical pulverization process. J. Appl. Polym. Sci. 2004, 93, 378-386. [CrossRef]

38. Qian, Z.; Qian, J.; Lerou, F.; Tanga, P.; Li, D. Antioxidant intercalated hydrocalumite as multifunction nanofiller for Poly (propylene): Synthesis, thermal stability, light stability, and anti-migration property. Polym. Degrad. Stab. 2017, 140, 9-16. [CrossRef]

39. Esthappan, S.K.; Kuttappan, S.K.; Joseph, R. Effect of titanium dioxide on the thermal ageing of polypropylene. Polym. Degrad. Stab. 2012, 97, 615-620. [CrossRef]

40. Nurul, M.S.; Mariatti, M. Effect of thermal conductive fillers on the properties of polypropylene composites. J. Thermoplast. Compos. 2013, 26, 627-639. [CrossRef]

41. Bhagat, N.A.; Shrivastava, N.K.; Suin, S.; Maiti, S.; Khatua, B.B. Development of electrical conductivity in PP/HDPE/MWCNT nanocomposite by melt mixing at very low loading of MWCNT. Polym. Compos. 2013, 34, 787-798. [CrossRef]

42. Zhou, T.Y.; Tsui, G.C.P.; Liang, J.Z.; Zou, S.Y.; Tangm, C.Y. Thermal properties and thermal stability of PP/MWCNT. Compos. Part B Eng. 2016, 90, 107-114. [CrossRef]

43. Hapuarachchi, T.D.; Peijs, T.; Bilotti, E. Thermal degradation and flammability behavior of polypropylene/clay/carbon nanotube composite systems. Polym. Adv. Technol. 2013, 24, 331-338. [CrossRef]

44. Yang, F.; Nelson, G.L. Polymer/silica nanocomposites prepared via extrusion. Polym. Adv. Technol. 2006, 17, 320-326. [CrossRef]

45. Chu, C.C.; White, K.L.; Liun, P.; Zhangn, X.; Suen, H.J. Electrical conductivity and thermal stability of polypropylene containing well-dispersed multi-walled carbon nanotubes disentangled with exfoliated nanoplatelets. Carbon 2012, 50, 4711-4721. [CrossRef] 
46. Al-Shere, S.Z.; Al-Amshany, Z.M.; Al Sulami, Q.A.; Tashkandi, N.Y.; Hussein, M.A.; El-Shishtawy, R. The preparation of carbon nanofillers and their role on the performance of variable polymer nancomposites. Des. Monomers Polym. 2019, 22, 8-53. [CrossRef]

47. Vega, J.; Martinez, J.; Trujillo, M.; Arnal, M.; Muller, A.; Bredeau, S.; Dubois, P. Rheology, Processing, Tensile Properties, and Crystallization of Polyethylene/Carbon Nanotube Nanocomposites. Macromolecules 2009, 42, 4719-4727. [CrossRef]

48. Vega, J.F.; da Silva, Y.; Vicente Alique, E.; Nuńez Ramírez, R.; Trujillo, M.; Arnal, M.L.; Müller, A.J.; Dubois, P.; Martínez Salazar, J. Influence of Chain Branching and Molecular Weight on Melt Rheology and Crystallization of Polyethylene/Carbon Nanotube Nanocomposites. Macromolecules 2014, 47, 5668-5681. [CrossRef]

49. Trujillo, M.; Arnal, M.; Müller, A.J.; Bredeau, S.; Bonduel, D.; Dubois, P.; Hamley, I.; Castelletto, V. Thermal Fractionation and Isothermal Crystallization of Polyethylene Nanocomposites Prepared by in Situ Polymerization. Macromolecules 2008, 41, 2087-2095. [CrossRef]

50. Trujillo, M.; Arnal, M.; Müller, A.J.; Laredo, E.; Bredeau, S.; Bonduel, D.; Dubois, P. Thermal and Morphological Characterization of Nanocomposites Prepared by in Situ Polymerization of High- Density Polyethylene on Carbon Nanotubes. Macromolecules 2007, 40, 6268-6276. [CrossRef]

51. Zhang, X.; Yan, X.; He, Q.; Wei, H.; Long, J.; Guo, J.; Gu, H.; Yu, J.; Liu, J.; Ding, D.; et al. Electrically conductive polypropylene nanocomposites with negative permittivity at low carbón nanotube loading levels. ACS Appl. Mater. Interfaces 2015, 7, 6125-6138. [CrossRef]

52. Laird, E.D.; Li, C.Y. Structure and Morphology Control in Crystalline Polymer-Carbon Nanotube Nanocomposites. Macromolecules 2013, 46, 2877-2891. [CrossRef]

53. Grady, B.P.; Pompeo, F.; Shambaugh, R.L.; Resasco, D.E. Nucleation of polypropylene crystallization by single-walled carbon nanotubes. J. Phys. Chem. B 2002, 106, 5852-5858. [CrossRef]

54. Bhattacharyya, A.R.; Sreekumar, T.V.; Liu, T.; Kumar, S.; Ericson, L.M.; Hauge, R.H.; Smalley, R.E. Crystallization and orientation studies in polypropylene/single wall carbon nanotube composite. Polymer 2003, 44, 2373-2377. [CrossRef]

55. Xu, D.H.; Wang, Z.G. Role of multi-wall carbon nanotube network in composites to crystallization of isotactic polypropylene matrix. Polymer 2008, 49, 330-338. [CrossRef]

56. Haggenmueller, R.; Fischer, J.E.; Winey, K.I. Single wall carbon nanotube/polyethylene nanocomposites: Nucleating and templating polyethylene crystallites. Macromolecules 2006, 39, 2964-2971. [CrossRef]

57. Funck, A.; Kaminsky, W. Polypropylene carbon nanotube composites by in situ polymerization. Compos. Sci. Technol. 2007, 67, 906-915. [CrossRef]

58. Wang, J.; Yang, J.; Deng, L.; Fang, H.; Zhang, Y.; Wang, Z. More dominant shear flow effect assisted by added carbon nanotubes on crystallization kinetics of isotactic polypropylene in nanocomposites. ACS Appl. Mater. Interfaces 2015, 7, 1364-1375. [CrossRef]

59. Maharramov, A.M.; Ramazanov, M.A.; Ahmadova, A.B.; Hajiyeva, F.V.; Hasanova, U.A. Structure and dielectric properties of nanocomposites based on isotactic polypropylene and titanium nanoparticles. Dig. J. Nanomater. Bios. 2016, 11, 781-786.

60. Sierra, R.; Pérez, M.; Valdez, J.; Ávila, C.; Jimenez, E.J.; Mata, J.; Soto, E.; Cadenas, G. Synthesis and Thermomechanical Characterization of Nylon 6/Cu Nanocomposites Produced by an Ultrasound-Assisted Extrusion Method. Adv. Mater. Sci. Eng. 2018, 2018, 4792735. [CrossRef]

61. Pan, Y.; Feng, H.K.; Li, L.; Chan, S.; Zhao, J.; Kay, Y. Effects of hybrid fillers on the electrical conductivity and EMI shielding efficiency of polypropylene/conductive filler composites. Macromol. Res. 2013, 21, $905-910$. [CrossRef]

62. Pan, Y.; Cheng, H.K.F.; Li, L.; Chan, S.H.; Zhao, J.; Juay, Y.K. Annealing induced electrical conductivity jump of multi-walled carbon nanotube/polypropylene composites and influence of molecular weight of polypropylene. J. Polym. Sci. Polym. Phys. 2010, 48, 2238-2247. [CrossRef]

63. Steinmann, W.; Vad, T.; Weise, B.; Wulfhorst, J.; Seide, G.; Gries, T.; Heidelmann, M.; Weirich, T. Extrusion of CNT-modified polymers with low viscosity-influence of crystallization and CNT orientation on the electrical properties. Polym. Polym. Compos. 2013, 21, 473-482. [CrossRef]

64. Ramazanov, MA.; Hajiyeva, F.V.; Maharramov, A.M. Structure and properties of $\mathrm{PP} / \mathrm{TiO}_{2}$ based polymer nanocomposites. Integr. Ferroelectr. 2018, 192, 103-112. [CrossRef]

65. Rafiee, R. Fabrication of carbon nanotube/polymer nanocomposite. In Carbon Nanotube-Reinforced Polymers: From Nanoscale to Macroscale; Elsevier: Amsterdam, The Netherlands, 2017; Volume 1, pp. 61-76. 
66. Song, Y.S.; Youn, J.R. Influence of dispersion states of carbon nanotubes on physical properties of epoxy nanocomposites. Carbon 2005, 43, 1378-1385. [CrossRef]

67. Zhao, Q.; Hu, Y.; Wang, X. Mechanical performance and flame retardancy of polypropylene composites containing zeolite and multiwalled carbon nanotubes. J. Appl. Polym. Sci. 2016, 133, 42875-42879. [CrossRef]

68. Apaydin, K.; Laachachi, A.; Ball, V.; Jimenez, M.; Bourbigot, S.; Toniazzo, V.; Ruch, D. Intumescent coating of (polyallylamine-polyphosphates) deposited on polyamide fabrics via layer-by-layer technique. Polym Degrad Stab. 2014, 106, 158-164. [CrossRef]

(C) 2019 by the authors. Licensee MDPI, Basel, Switzerland. This article is an open access article distributed under the terms and conditions of the Creative Commons Attribution (CC BY) license (http://creativecommons.org/licenses/by/4.0/). 